\title{
Make meat-eaters pay: Ethicist proposes radical tax, says they're killing themselves and the planet
}

\author{
AUTOR: Peter Singer \\ TÍTULO: Make meat-eaters pay: Ethicist proposes radical tax, says they're killing \\ themselves and the planet
}

FECHA DE PUBLICACIÓN: 25.10.2009

LUGAR DE PUBLICACIÓN: New York Daily News

Reproducido con autorización expresa del autor en: derecho Animal web Center, febrero 2010

\footnotetext{
Taxes can do a lot of good. They pay for schools, parks, police and the military. But that's not all they can do. High taxes on cigarettes have saved many lives - not only the lives of people who are discouraged from smoking as much as they would if cigarettes were cheap, but also the lives of others who spend less time passively inhaling smoke.

No reasonable person would want to abolish the tax on cigarettes. Unless, perhaps, they were proposing banning cigarettes altogether - as New York City is doing with transfats served by restaurants.

A tax on sodas containing sugar has also been under consideration, by Governor Paterson among others. In view of our obesity epidemic, and the extra burden it places on our health care system - not to mention the problems it causes on a crowded New York subway when your neighbor can't fit into a single seat - it's a reasonable proposal.

But in all these moves against tobacco, transfats and sodas, we've been ignoring the cow in the room.

That's right, cow. We don't eat elephants. But the reasons for a tax on beef and other meats are stronger than those for discouraging consumption of cigarettes, transfats or sugary drinks.

First, eating red meat is likely to kill you. Large studies have shown that the daily consumption of red meat increases the risk that you will die prematurely of heart disease or bowel cancer. This is now beyond serious scientific dispute. When the beef industry tries to deny the evidence, it is just repeating what the tobacco industry did 30 years ago.
} 
Second, we have laws that ban cruelty to animals. Unfortunately in the states in which most animals are raised for meat, the agribusiness lobby is so powerful that it has carved out exemptions to the usual laws against cruelty.

The exemptions allow producers to crowd chickens, pigs and calves in stinking sheds, never letting them go outside in fresh air and sunlight, often confining them so closely that they can't even stretch their limbs or turn around. Debeaking - cutting through the sensitive beak of a young chick with a hot blade - is standard in the egg industry.

Undercover investigations repeatedly turn up new scandals - downed cows being dragged to slaughter, workers hitting pigs with steel pipes or playing football with live chickens. We may not be able to improve the laws in those farming states, but taxes on meat would discourage people from supporting these cruel practices.

Third, industrial meat production wastes food - we feed the animals vast quantities of grains and soybeans, and they burn up most of the nutritional value of these crops just living and breathing and developing bones and other unpalatable body parts. We get back only a fraction of the food value we put into them.

That puts unnecessary pressure on our croplands and causes food prices to rise all over the world. Converting corn to biofuel has been criticized because it raises food prices for the world's poor, but seven times as much grain gets fed to animals as is made into biofuel.

Fourth, agricultural runoff — much of it from livestock production, or from the fertilizers used to grow the grain fed to the livestock - is the biggest single source of pollution of the nation's rivers and streams, according to the EPA. A meat tax would be an important step towards cleaner rivers. By reducing the amount of nitrogen that runs off fields in the Midwest into the Mississippi, it would also stop the vast ?dead zone? that forms in the Gulf of Mexico each year.

The clincher is that taxing meat would be a highly effective way of reducing our greenhouse gas emissions and avoiding catastrophic climate change.

Here's just how bad eating meat is for global warming.

Many people think that buying locally produced food is a good way to reduce their carbon footprint. But the average American would do more for the planet by going vegetarian just one day per week than by switching to a totally local diet.

In 2006 the United Nations Food and Agriculture Organization surprised many people when it produced a report showing that livestock are responsible for more emissions than all forms of transportation combined. It's now clear that that report seriously underestimated the contribution that livestock — especially ruminant animals like cattle and sheep - are making to global warming.

As a more recent report by the Intergovernmental Panel on Climate Change has shown, over the critical next 20 years, the methane these animals produce will be almost three times as potent in warming the planet as the FAO report assumed.

Meat-eaters impose costs on others, and the more meat they eat, the greater the costs.

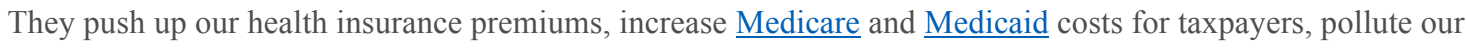
rivers, threaten the survival of fishing communities in the Gulf of Mexico, push up food prices for the world's poor, and accelerate climate change. 
Red meat is the worst for global warming, but a tax on red meat alone would merely push meat-eaters to chicken, and British animal welfare expert Professor John Webster has described the intensive chicken industry as "the single most severe, systematic example of man's inhumanity to another sentient animal.

So let's start with a $50 \%$ tax on the retail value of all meat, and see what difference that makes to present consumption habits. If it is not enough to bring about the change we need, then, like cigarette taxes, it will need to go higher.

Singer is professor of bioethics at Princeton University, the author of "Animal Liberation" and the author, with Jim Masion, of "The Ethics of What We Eat." 